\title{
A challenge to change developments in feminist theology and feminist Christology
}

\author{
Riet Bons-Storm (The Netherlands) ${ }^{1}$ \\ Research Associate: Department of Practical Theology \\ University of Pretoria
}

\begin{abstract}
Contextual theologies have made it clear that context, and the particular experiences a context gives, shapes thinking about the Divine and the world into a particular, contextual theology. Feminist theologians stress the point that the life-experience of women in general - and every woman of flesh and blood in particular - works as a context, seeing the world, thinking about the Divine from a particular perspective. The critique of feminist theologies is aimed in the first place to the presumptions and assumptions underlying texts, customs and politics. Feminist theologians ask basic questions about the acquisition of theological knowledge that exposes the cultural conditioning of Christian belief. This review article on the work of Lisa Isherwood and Dorothea McEwan demonstrates how many feminist theologians find in "Process Thought" a way of thinking that avoids the suppositions these presumptions and assumptions make.
\end{abstract}

\section{FEMINISM, WHAT WAS IT, WHAT IS IT NOW?}

Lisa Isherwood and Dorothea McEwan issued a second edition of their book Introducing feminist theology, first published in $1993^{2}$. This new edition shows that feminist theology is alive, kicking, and developing in richness. Lisa

\footnotetext{
${ }^{1}$ Review Article: Isherwood, L \& McEwan, D [1993] 2001. Introducing feminist theology. Sheffield: Sheffield Academic Press; Isherwood, L 2001. Introducing feminist Christologies. Sheffield: Sheffield Academic Press. Prof Dr Riet Bons-Storm Prof is Emeritus-Professor at the University of Groningen (the Netherlands) and a member of the International Advisory Board of HTS Theological Studies. She is a research associate of Prof Dr Yolanda Dreyer, Department of Practical Theology, University of Pretoria.

${ }^{2}$ Both editions are published by Sheffield Academic Press (1993 and 2001). See the short review by Prof Christina Landman in HTS Theological Studies, 60(3) September 2004, 12331234.
} 


\section{A challenge to change developments in feminist theology}

Isherwood wrote Introducing feminist Christologies ${ }^{3}$. Both books are published in the series Introductions in feminist theology. ${ }^{4}$ These two books offer an opportunity to look anew at feminist theologies and their development.

For many men and women "feminism" is a word heavy with prejudice: images of women who no longer want to be acceptable and attractive. Isherwood and McEwan understand feminism as "a way of looking at society and centring the concerns of society on women and men" (IM, p 9). This definition shows that feminism is not for women only. Here we come across an important development in feminist theology. The rise and fall of feminist waves during the last decades with its emphasis on women, their oppression and struggle for liberation, has evolved into an emphasis on women-and-men, on the meaning of existing as sexual beings, which means being "gendered" human beings in society. Where in the 60 s the emphasis was on the liberation of women, now another very important issue is: how can women and men live together in a new way $?^{5}$ Decades of feminist endeavours in society, church and university were not in vain. Patriarchy is not as strong as it was, but it is still there.

Isherwood and McEwan summarize patriarchy in a short and clear way: it is a culture with Man as the norm (IM, p 26). Biology became destiny. Feminism arose out of the experiences of multi-layered oppressions, it "is about women refusing to be controlled by definitions of who and what we are and what we should be" (IM, p 9). Their book is written from the perspective of women. The "we" is always women. Men who identify with women, however, are included in this "we." The experience of being oppressed is not only - but that also - being beaten, being locked into confined spaces, literally or metaphorically. Oppression, often not visible by the naked or naïve eye, is also exclusion. Oppression - by conventions, by legislations, by synods forbids one to be what one could be if one's gifts were to be brought into bloom. Oppression stifles creativity.

Isherwood and Mc Ewan, as feminists of today, do not focus solely on women and their oppression, as was necessary in former decades. Then anger and lament prevailed. The insight nowadays is that patriarchy has made more victims than only women. There are indeed also many powerless men. Already in the 80s Elisabeth Schüssler Fiorenza ([1985] 1986:27) wrote about the complications of patriarchy. Patriarchy is not about "all men oppressing all

\footnotetext{
${ }^{3}$ Sheffield Academic Press, 2001. When I refer to these books, I shall use IM, when referring to the book by Isherwood and McEwan, and I, when I refer to the book of Isherwood.

${ }^{4}$ Editorial Committee: Mary Grey, Lisa Isherwood, Catherine Norris and Janet Wootton.

${ }^{5}$ See also: "From generation to generation; horizons in feminist theology or reinventing the wheel". Journal of Feminist Studies in Religion 15(1) Spring 1999, 103-138.
} 
women", but about a male dominated pyramid of varied oppressions, for instance racism and classism. Power from a patriarchal perspective can be defined as the possibility to restrict the choices of another person or: as the possibility to determine the thoughts, emotions, language and behaviour of somebody else. In patriarchy this power is ascribed in the first place to the father. The Supreme Father, who in religious language becomes God the Father, owns the whole world and is (was) presumably White. Being like the Supreme Father - being male, having means, money, being White - is sharing in his power, it provides power-factors. The more one resembles the Father, the more power-factors a person can claim. So women are always rather low on the ladder. Poor men, homosexual men, who will not become fathers and Black men also lack the power-factors to rise to higher rungs of the ladder. The way to rise on the patriarchal ladder is: deny what you really are and try to be like the Supreme Father (cf Riet Bons-Storm 1992).

Isherwood and McEwan point at the fact that women became stronger, bolder, supporting each other. More and more women grasped the courage to try and develop their gifts, notwithstanding the still strong message in many parts of society and churches that they have to play the role of the dependent woman, obeying the definitions of men. They protested the confined positions men gave them. Many women came out of their "surrender-mentality" and started to define themselves. They aspired to power, but to power defined in a different way: not to restrict, but to achieve positive change, power leading to empowerment of others. Women began making their own decisions (IM, pp 28 ff and 43).

Isherwood and McEwan make it very clear that feminist theology is not about allowing some women to rise to higher rungs on the ladder, not about putting one Woman at the top, but about throwing away this ladder. The project of feminism is "to deal with the experiences and concerns in the realm of everyday living; to make connections to enhance the practical and ethical solutions; to connect individual and social demands; to facilitate human endeavours to form relationships built on mutuality and to grow relationship with the Divine" (IM, p 9). They state: "As Christians we come from a misogynist tradition" (IM, p 9). However, throughout their book Isherwood and McEwan emphasize that there always were dissenters, non-conformists asking critical questions about the division of power and influence.

The critique of feminist theologies is aimed in the first place at the presumptions and assumptions underlying texts, customs and politics. This is what makes the project of feminist theologies so dangerous: if the presumptions and assumptions change, the whole construct of Christian theology will change. 
Feminist theologians ask basic questions about the acquisition of theological knowledge, "exposing the cultural conditioning of Christian belief" (IM, p74). They acknowledge that theological knowledge, which became part of the canon of Christian tradition, is based on the life-experience of men. These were mostly men who adhered to the ideology of patriarchy. From that point of view they saw those who were on lower rungs of the patriarchal ladder, women always included, as objects, in the best case to be guided, in the worst case to be marginalized or ignored. While men unconsciously knew that they were of the same gender as God the Father, women were far from God, completely different. And thus the appropriate attitude of women was to be obedient. Although some women have been allowed to rise a few rungs, the ladder is still firmly held upright by all those who reap its benefits: status and higher wages. One of the changes in feminism is that the accusing finger no longer points at (macho) men, but rather at patriarchy and its assumptions and effects. Of course, there is still anger towards those men (and women) who behave towards women in a patriarchal way, and who should know better after decades of feminist and feminist theological writing.

The development of contextual theologies in the last decades has made it clear that context, and the particular experiences a context gives, shape one's thinking about the Divine and the world into a particular, contextual theology. Feminist theologians stress the point that the lifeexperience of women in general - and every woman of flesh and blood in particular - functions as a context, seeing the world, thinking about the Divine, from a particular perspective. This perspective opens new vistas. Being a man, always with a particular life-experience in a particular place in society, also renders a context, with its own perspective. But maintaining that theology from a male perspective is the only trustworthy theology, means that one acknowledges with only half of theology.

Patriarchy divides everything into polar opposites, assuming that one of the opposites is positive, the other negative. Female and male, emotions and ratio, body and soul are opposite. Feminist thought tries to find a way out of this age-old dualistic thinking (IM, p 74).

Process Thought provides the tools to do só (IM, p 78-85). Alfred North Whitehead $(1929)^{6}$ did not understand the world as divided into dualities, but as relational. Everything exists in relation to everything else. We are connected to everything else. From this understanding Whitehead concluded that the aim of life was not to develop objective thought, but empathic feeling. According to him we partake in the creative process and really understand our

\footnotetext{
${ }^{6}$ Isherwood and McEwan refer mostly to Whitehead's (1929) Process and reality. New York: Macmillan.
} 
true destiny only when we realize that we are co-creators of the universe. This means that human beings are always in the process of becoming. Decisionmaking is of crucial importance in shaping the future, as human beings are capable of rational enquiries and of being responsible. But in this rational process we are nevertheless always affected by our surroundings.

In Process Thought, God is not understood as a person in the first place, but as the complete of possibility for a good and just life. The Divine is understood as the Life Force, in the form of the Holy Spirit enhancing all endeavours toward justice and abundant life for all. Life itself, which belongs to God, is sacred. Isherwood and McEwan show how Process Thought provides a way of thinking which avoids the suppositions of patriarchy. They follow the thought of Sallie McFague, Mary Grey, Carter Heyward and Elisabeth Johnson who show, in a more elaborate way than was possible for Isherwood and McEwan in their Introduction, how Process Thought can shape (feminist) theology. ${ }^{7}$

This pardigm shift in theology has consequences for all sections of theology. Truth is no longer that which is pronounced or approved of by the Almighty Father and those who possess sufficient power-factors to represent him and proclaim the truth in an authoritative way. In a world where people meet and mutually exchange their views - with the ladder gone - truth can be discovered through the life-experience of its meaning (IM, p 74). Lifeexperience is a source of truth. This has always been the case, only, the lifeexperience of men possessing power-factors, was seen as the place of the revelation of the universal truth - its particular origins forgotten or suppressed. Feminist theology also honours the life-experiences of women.

Women have different circumstances and various amounts of powerfactors, as seen from a patriarchal perspective. When feminism and feminist theology started developing, "the sisterhood of all women" was a powerful concept. But African-American feminist theologians protested: their lifeexperience was quite different from that of White women. They proceeded to claim their own theology (IM, p 94) (see Grant 1989).

\footnotetext{
${ }^{7}$ Of each of these writers I take here only one or two books as examples. All have written more.

- $\quad$ Sallie McFague 1987. Models of God: Theology for a nuclear age. London: SCM.

- Sallie McFague 1993. Super Natural Christians: How we should love. London: SCM.

- Mary Grey 1989a. Weaving the connections: The promise of process thought for Christian Theology. Katholieke Universiteit Nijmegen.

- $\quad$ Carter Heyward 1982. The redemption of God. A theology of mutual relation. Washington, DC: University of America Press.

- $\quad$ Carter Heyward 1989. The erotic as power and the love of God. New York: Collins.

- Elisabeth A Johnson 1993a. Women, earth and Creator Spirit. Mahwah, NJ: Paulist Press.
} 
The life-experience of lesbian women had also to be taken seriously as a source for theological reflection. Lesbianism is anathema in a patriarchal world. "... lesbianism is feared because it poses a threat to the nuclear family, the economic order, the gender of God, gender appropriate roles in the home, the norm of procreation, the sanctity of marriage and the acceptance of dominant-submissive relationships that are prevalent in all aspects of society" (IM, p 130, quoting Carter Heyward 1989:297).

Ethnicity, class, orientation, all provide their own contexts and lifeexperiences; their own perspectives for theological reflection. "This has meant that feminist theology has grown apace and now represents us with a rainbow of liberative possibilities" (IM, p 95). This development has presented a problem and an opportunity for feminist theology in general. The problem was that the idea of a self-evident universal sisterhood was shattered. It was easy for the opponents of feminist theology to rejoice in the divides among feminists. The opportunity for feminist theologians was to think about the meaning of difference (IM, p 125). The eyes of feminists were opened to the fact that they were very human, had all the weaknesses of humanity, among others: not looking beyond the boundaries of their own context. Nowadays feminist theology is trying to come to terms with diversity and with the guilt feelings this may cause. A white Western feminist should see herself not only as a victim of patriarchy, but also as an accomplice to colonial and other forms of oppression, having internalized the patriarchal attitude to people supposedly on the lower rungs. Isherwood and McEwan call "difference" "the meeting point with God and the self" (IM. p 125). In the "Other", who is different, one meets the different way God speaks to the Other in her particular situation. The Other is always in principle a grace-filled person, although she may not be aware of it, or even try to deny it. Meeting the Other makes a person aware of her own experiences and the way God possibly speaks in those experiences. In this sense "meeting" somebody else opens up holy ground. This may be the locus, the concrete place, where God's will can be done, God's longing fulfilled: there right relation may grow.

Isherwood and McEwan comment as follows on global sisterhood: "Sadly there does not seem to be anything to replace it" (IM, p 95). I do not agree with them. What is emerging is a forum where more and more feminist theologians can meet, tell the story of their life, exchange perspectives, struggle, fight sometimes (women are human when all is said and done) and sometimes form "unlikely coalitions."

\footnotetext{
8 "Unlikely coalitions" is a term introduced by Mary Hunt (1991) in her book Fierce tenderness: A feminist theology of friendship. New York: Crossroad.
} 
In this way the principles of Process Thought are put into practice: We are not sisters yet, but we are in the - sometimes long and difficult - process of becoming allies, looking for places where our contexts, our interests, our longings meet. Feminist theology is no longer a project of only white, Western middle-class women. In Ghana Mercy Amba Oduyoye, in Egypt Marie Assad, in Kenya Bette Ekeya, in Cameroon Luise Tappa, in India Aruna Granadason, in Indonesia Marianne Katoppo, in Korea Chung Hyun Kyung, to name just a few, are women who have contributed to the development of various feminist theologies (IM, pp 21-22).

\section{THE PRESUMPTION OF THE STATIC, GOD-WILLED ORDER OF SOCIETY VERSUS LIBERATION THEOLOGY}

Next to Process Thought, Liberation Theology can be a tool, for overcoming the basic assumptions of patriarchy and its effects (IM, p 85-91). Not that Liberation Theology as we know it is always anti-patriarchal. Its assumption, however, that society is not static and God is not on the side of the most powerful in a patriarchal sense, opens up ways of thinking where the situation and the voice of women can also be taken seriously. "Liberation Theology understands itself as dialogue between scripture and tradition on the one hand and the concrete daily life experiences of the people of God on the other" (IM, p 89). Liberation theologians argue that the Scriptures show God working in history. With the incarnation of God in Jesus we are given to understand that there is a connection between history and salvation. Contemplation is important. Out of this contemplation we reflect on concrete situations. Out of this reflection we discern that a very great part of humanity lives in circumstances that deviate from the way God created them: namely good. All people are grace-filled by the grace of God. As such all people can reflect on their concrete situations. Out of their experiences they can say important things about God. They can, in fact, do theology. These voices invite commitment. Faith does not show itself by saying to God "Lord, Lord", but by doing the will of the Father (Mt 7:21). God's will has to be done on earth as it is in heaven (Mt 6:10).

Liberation theologians are often accused of being Marxist. But criticizing the order of society and asking how the poor became poor is not an exclusive privilege of Marxism. It is an implication of the command to love our neighbours and take their well-being to heart. As in Liberation Theology "Feminist theologies supply the tools to make the shift from seeing religion as controlling life or the world to seeing religion as valuing the contribution of each and everyone" (IM, p 12). Nowadays it is often said that Liberation Theology is outdated. Right Wing policies in many countries are not interested 


\section{A challenge to change developments in feminist theology}

in valuing the voice of the poor and in rocking the patriarchal ladder with its emphasis on possessions as a strong power-factor. People lose their hope of the possibility to work towards a just world in God's name. Feminist theologies however try to kindle this hope ever anew, because still so many women and men are oppressed in so many ways. Small steps will bring us into the right direction.

\section{THE BASIC ASSUMPTION OF FEMINIST THEOLOGY: THE DIVINE STANDS FOR JUST RELATION}

Feminist theology works in the following steps of discernment:

- scrutinize writings of theology, history, doctrine, scriptures to find the sources of oppression, the presumptions and assumptions, the faulty interpretations that dictate what women are and are not allowed to do and what is pleasing to God, referred to as father;

- search in the same sources for the liberating strands that have been obscured, redacted out, in the Christian tradition (IM, p 13).

These steps put Isherwood and McEwan into the group of feminist theologians who still give Christian tradition and churches the benefit of the doubt or, even more, firmly believe that the core of the Gospel is about good news for those who have no voice. However, an ever growing group of feminist theologians lose hope that churches will ever abandon their patriarchal assumptions. They leave their churches.

Isherwood and McEwan see the Sermon on the Mount and the command to love one another as neighbours as the central message of the Gospel. "Christianity has a vision of making living together possible, interacting on a personal and societal level beyond classism, racism and sexism. But measured against the history of the last 2000 years, this vision has spectacularly failed to be put into practice" (IM, pp 13-14). Feminists and feminist theologians who still want to be called "Christian" share the basic belief that the God of Jewish and Christian tradition abhors patriarchy. Patriarchy and all its effects can be called "sin", because, by living the assumptions of patriarchy, many creatures of God are harmed, oppressed and killed. This perspective leads to the necessity to reconstruct theology. The result is a radically different understanding of the key-teachings of the Christian tradition.

The key-word in most feminist theologies is love, not taken as an abstract concept, but as a way of life. Feminist theology, with its roots in life- 
experiences, everyday experiences, and the emphasis on concrete justice, understands theology as "acting the faith and not just verbalizing and articulating it". Out of this "acting" arise formative experiences leading to liberation (IM, p. 94). Love outside the realm of the ladder does not necessarily think in "upper-under" terms, but leaves room for mutuality in equality.

This concrete love can be characterized as friendship and includes erotic qualities. In friendship we call forth the best in one another, it gives opportunities to call forth new patterns of relating that reflect values of love and justice between people. Mary Daly (1984), Mary Hunt (1991) and Carter Heyward (1989) reflected upon the concept of friendship and the erotic. Already in 1984 Mary Daly launched the term "Be-friending." Daly limits herself to the Be-friending amongst women. In patriarchy women-friendship is a subversive tool, being discredited by patriarchal men. They wanted for women to direct their most important allegiance and all intimacy towards them, the men. One of the tools for maintaining patriarchy in practice was the attempt to keep women apart, to set them up against one another in jealousy. Be-friending, in Daly's words, goes against our "ghettoization" from each other. Daly is aware that not all feminists will be friendly with one another, either because they do not know one another, or because of clashes in personality and opinion. Be-friending however creates a context where women, free from the patriarchal gaze, can find out who they are and how they can participate in society. Hunt takes up this idea of friendship and elaborates on it from a theological perspective. We may be friends with one another and friends with the Divine, as Jesus said: "I have called you friends" (Jn 15, 15; IM, p 127). Friendship is more egalitarian than romantic love, marital love or charity-love can ever be. It is always about finding one's own strength to be a friend, to act love, and to learn to accept love from somebody else, strengthening one another. Hunt puts "friendship" in the wider realm of society: the aim is justice: just relations. It is about widening one's horizon, venturing into the world and creating "unlikely coalitions".

Another thought that is basic in feminist theologies, which flavour the whole of theology, is the idea that right relation, "friendship", unlikely coalition, is erotic. The meaning of the erotic is taken out of the realm of (hetero)sexual attractions and activities and given a broader sense as the creative power of our embodied being (IM, pp 125-127). The heritage of Process Thought is clear in the assumption that there can be no dichotomy between nature and Spirit. They are not the same, but they are related and there is no upper-under relationship. Nature, the creation in its totality, is affirmed as sacred. That means: God dwells and works in it, continues to create in it. We are created 


\section{A challenge to change developments in feminist theology}

as embodied beings and this can be our strength. This strength can be used to make or to break others: the body is also a locus of violence. But we may believe that God's grace dwells in our embodied selves.

Women, even more than men, are known to have a complicated relationship with their bodies. They had to cherish it, beautify it, and change it, mainly in order to be attractive to men. Woman's body was - and often still is - not her own. Many girls still hear from a very young age that they have to preserve their bodies for that man, the disguised prince on a white horse, who will conquer her, to make her a full person, taking possession of her body. Her body: receptive vessel for his semen, earth where the semen may grow into his babies: the children who will bear his name. This body is the place of her vulnerability. The body is the place of shame, of guilt. It can never be "good". Isn't she Eve, who brought sin into the world? Since its inception, feminist theology was all about reclaiming our bodies, because the physical is also a vehicle for the Divine and passion is sacred (IM, p 125). This idea has not changed, for it still needs to be voiced. There is still much rape, sexual harassment, criticism of not-perfect - that is not attractive or young - bodies.

Passion is looked at with suspicion and dread in patriarchy. Passion threatens autonomy and brings chaos to the order controlled by the Almighty Father, who is seen by many to restrict passion to the instant when the semen fertilizes the egg, in order to beget sons. Feminist theology reclaims passion and understands it in a positive way. Passion, sexual passion included, is empowering. It is the energy that works in just relations. "Once we move from the abstract to the embodied we open again the power of empathy and imagination" (IM, p 126).

Feminist theological thought makes it self-evident that we have to take the ecological into the theological realm. We and the earth and all creatures in it are connected. Our fates are intertwined, as we realise nowadays, often painfully. How we care for, "be-friend" nature, behave reverently towards her air, soil and waters, is directly connected with the possibilities of us all to live a healthy life, without hunger and thirst. The most vulnerable and powerless, people in the so called Third World, are already suffering.

\section{THE PERCEPTION OF "TRADITION"}

Changing theologies and abandoning patriarchy are often hindered by the argument that tradition has to be maintained. Isherwood and McEwan agree with the definition of "tradition" given by Gustav Mahler: "Tradition is not the worship of the ashes, but keeping the fire alive." They say about tradition: "the handing over of tales, beliefs, practices, is a healthy way of incorporating the wisdom of our foremothers into our experiences. It becomes unhealthy when 
the past is only allowed to live on in one-sided representations of the past, called 'truth', and the present with all its flux and flow is deemed to be disruptive of that which is termed truth" (IM, p12). Tradition is about being in an open conversation with our foremothers and forefathers, with Scripture and scriptures, knowing that they, in their time and context, tried to live by and articulate faith in God as honestly as possible. They were not super-human, they interpreted their experiences in the spirit of their time, laden as always is the case, with ideologies.

Patriarchy has long since been the reigning ideology, because the relationship of men and women - so alike and so different, and who is the boss - is one of the most important relationships among human beings. There were always dissenters. So it is very important to listen to the voices of the people who critiqued the reigning ideologies. These persons were marginalized and swept under the carpet of history. Their voices should be reclaimed and critically woven into the fabric of tradition.

\section{THE POWER OF LANGUAGE: WHO IS AFRAID OF A GODDESS?}

"It is not only sticks and stones that hurt, but words hurt as well. Words create; patriarchal words about a patriarchal God have created our Western culture" (IM, p 118). Since its beginning feminist thought was very aware of the power of language. Isherwood and McEwan show very clearly that language and thought are intimately bound together. Language indicates how women are perceived. Hearing church-language was and still is for many women the first step to awareness and anger. To use male words - he, his, him - for human beings, women included, conjures up masculine images, as research has shown (IM, p 108).

It is difficult for many men to really understand how important language in theology and church is for women. Men are blissfully unaware of the fact that they are constantly affirmed in their gendered being by the language commonly used in theology and the church. They are used seeing themselves as the representatives of "mankind". Even sophisticated theologians are often unconsciously convinced in their heart that of course God has no genitals, but still He is male. ${ }^{9}$ How else could He sit on the highest rung and be Almighty? To see God as female, as Goddess, is very often seen as reducing God to a symbol of fertility. This reveals that women are seen as reduced to their fertility. I contend that a test-case for a non-patriarchal attitude is the question

\footnotetext{
${ }^{9}$ See Howard Eilberg-Schwartz (1994), God's phallus: And other problems for men and monotheism. Boston. Eilberg-Schwartz is Associate Professor and Director of Jewish Studies at San Francisco State University and an ordained rabbi (cf Biezeveld 2001:85-96).
} 


\section{A challenge to change developments in feminist theology}

whether somebody can imagine and worship a female Deity and is not afraid of calling God Goddess.

The traditional articulation of creation is disastrous for women, who hear it with their ears wide open. The Goddess-imagery is still alive in the Serpent, symbol of the Goddess of Regeneration, Wisdom and Healing. But She is discredited and humiliated. "Within the context of Goddess worshipping it would have been quite understandable and acceptable that the serpent should encourage the woman to seek knowledge .... However, the biblical story is written from the point of view of male monotheism" (IM, p 112).

The strength of women to be able to bear children became a curse and equal partnership with man was destroyed (Gn 3:16, 17). The Genesis-story justifies blame-filled dominance and makes creative equality between men and women impossible. Of course this story is read nowadays as defined by its context. But seldom the consequences for the self-worth and faith of women are taken into account.

Feminists read the Genesis-story with new eyes to see the power struggle it reflects between the Male God, Warrior, Protector of cities and religious institutions, Keeper of Order and Father of Sons on the one hand and Goddesses, representing not only fertility, the Circle of life, birth, survival and death, but also Wisdom. In the 60s and 70s much emphasis was placed on this God-language. Many feminists wanted a Goddess to replace the male God. Nowadays more attention is given to articulating a Divine Being who is non-gendered, encompassing both genders. God can be called "Father", but can also be called "Mother". If one wants to speak about the Divine in anthropomorphic language feminist theologies are against portraying the Divine as exclusively male. What remains is the longing of many women for a Divine Being who is not ashamed of being called She and imaged as female. This longing is very deep and it colours the spirituality of many women in theology and the churches. It is the longing to be accepted as they are, gendered, female embodied beings and as such fully human. Not the same as men, but of equal worth.

Equality is hardly thinkable in patriarchy. But the Divine created them as men and women, creating diversity with all its excitement. Recently Marcella Althaus-Reid expanded on these ideas. The starting point of her book, Indecent theology: Theological perversions in sex, gender and politics, is: "All theology is sexual theology" (Althaus-Reid 2000:1). Because of the dualistic divide between maleness and femaleness - the most important duality in patriarchal ideology - each and every argumentation implies ideas and emotions linked with sexuality. What is needed is Indecent theology: saying things that are not regarded as decent, as acceptable and conforming to the rules in patriarchal theology. In Western/patriarchal theology "Jesus has 
become a monopoly with strict control on spiritual production of meaning and exchange. However, at the grassroots there is always discontent with the unreality and oppressive powers of these theological meta-productions of God and Jesus" (Althaus-Reid 2000:95). Jesus has to be drawn out of the implications of his "maleness" in traditional theology. "... Queer liberationists may rightly see in Jesus someone with whom out-of-the-closet lesbians, gays, bisexuals and heterosexuals can identify. This is a very positive step, but an Indecent Theology must go further ... it must go beyond the positive identification with a larger Christ." Christ must be sexually deconstructed. The issue is "not just to debate the maleness of Christ per se as in an oldfashioned style of Feminist Theology. It has to raise doubts, showing in this process the construction of this sexual Christology, which does not necessarily edify the heterosexual patterns, although it fortifies them ad infinitem ..." (Althaus-Reid 2000:95).

But we find it very difficult to transcend the patriarchal categories that have been imposed on us. "Even the language that we as women have, is colonized by patriarchal logic and androcentric bias, thereby making it impossible for us to express the meaning that we embody through our experiences. We are literally speechless" (I, p 38).

\section{COULD THE WORD BECOME FEMALE FLESH?}

Jesus as Saviour is a key-concept in Christian theology. Feminist theological thinking about Jesus Christ became a hot issue since the energizing debate between Daphne Hampson and Rosemary Ruether in 1990 that hinged on the issue as to whether faith in Jesus was incompatible with feminism. The book Introducing feminist Christologies, written by Lisa Isherwood, takes a stand in this debate. Isherwood states that Jesus can be salvific for women when they themselves think about him, critically listening to the Christian tradition, and listening to women's voices coming out of their life-experiences.

Many women are not touched by the traditional gospel of the only Son of the Father God who by his suffering atoned for the sins of mankind and opened again the way to the Father. "The maleness of Christ as imaged through the centuries has damaged women's self-esteem by relaying us to second-class citizens. In addition it has removed us from valuable images of the female divine" (I, p 31). Women experience that their lives do not speak of sacrifice and suffering as salvific. The idea of the suffering servant delivered women into the often abusing hands of Christian fathers and husbands.

The concept of "sin" is formative in traditional christologies. This "sin" was predominantly associated with women. In the 80s Judith Plaskow stated that for women hybris was not the ultimate sin, but self-abnegation. It is Plaskow's conviction that consciousness-raising groups have assisted women in becoming aware of the "social context" of both sin and grace (Plaskow 
1980:170-171). Isherwood departs from this point. She makes us look at several feminist christologies, not in contradiction with each other, but each, in its context, giving attention to particular points. It is important to ask the question: what is a person being redeemed from? $(\mathrm{I}, \mathrm{p} 28)$. There can not be one universal theory of sin and salvation. "Feminist redemption theories then move us away from the absolutes of some human/divine being having done it all: to an on-going process that requires our full understanding and participation in the complex business of 'being human'. This requires overcoming the myths of gender construction more than dealing with an inborn and innate ability to sin" (I, p 29).

\section{GOD INCARNATE IN HUMANITY: THE CHRIST OF RELATIONAL POWER}

Marcella Althaus-Reid states (1996:136): "The fact is that the Christological process starts not with the first meetings of church councils but with the construction of the Christ, the Messiah, a process that depends on the interrelationality between a man called Jesus and a community of women, men and children" (I, p 68). Women meeting Jesus and doing theology, suffering from patriarchal dualistic thinking that put them firmly into the realm of body, flesh and sexuality, took incarnation seriously. Leaping over the dualistic division male-female, they believed that the Divine - also not male, nor female, or both - was incarnated in a human being and as such, in humanity in this world. Jesus as incarnation happened to be male. But it is not Jesus as divine person, being the only Son of God who saves or liberates. Jesus is an icon, a shining example of persons who, in the course of history, have lived in a way that shows others how the Divine is, and what humanity really is and can be. Jesus had "messianic quality" in a striking way, but others can also have this "messianic quality". ${ }^{10}$ This gives way to female imagery of the Christ. Edwina Sandys sculpted the first contemporary Christa, a female hanging on the cross, in 1975. Many women were touched and empowered by this image. Many persons were disgusted, finding a crucified woman an impropriate image as a Christian icon (I, p 103).

Taking the embodiment, the humanness of Jesus seriously, draws attention to Jesus' relationality, his touching and healing of people. Mary Grey can be an example of feminist thinkers who apply the ideas of Process Theology and relationality to Christology. According to Grey (1989b:36; see Isherwood 2001:29-30), if one accepts that interrelationality and mutuality in equality are "at the heart of reality, at the heart of the great divine creative-

\footnotetext{
${ }^{10}$ See for instance Riet Bons-Storm (1991:51-69): "Een mens met messiaanse kwaliteiten. Jezus Christus en het Vrouwenpastoraat", in Manuela Kalsky \& Theo Witvliet (reds), De Gewonde Genezer: Christologie vanuit het perspectief van vrouwen uit verschillende culturen, Manuela Kalsky en Theo Witvliet. Baarn: Ten Have, 1991, pp 51-69.
} 
redemptive dynamism, participating in this must be 'holiness' ... Sin must therefore be acting against the relational grain of living." Jesus is the icon of relational living and dying. He stands for Sophia, the Wisdom of Fools (Grey 1993), who reveals to us who God is, "She is shouting 'epiphanies of connections' between people and the planet but also makes plain the ethical implications and empowers the action" (I, p 113).

Rita Brock (1988) and Carter Heyward (1982) are two feminist theologians who explicitly name the relational power of Jesus - and so also the relational power of people who embody the Divine - as erotic. Not agape, an important concept in Christian tradition, but eros, that engages people's embodied selves, redeems both the world and Christ. Brock states that we are, like Jesus, broken-hearted healers. The only way to heal both others and ourselves is in and through our vulnerability. "Brock wishes to redeem Christ from being a victim and from being a hero, which is what she says liberation theology does to him (I, pp 55-56). Jesus' and our vulnerability is a power in striving at just and healing relations (Brock 1988; Heyward 1982).

Some feminist theologians include relationships with nature, the earth, the cosmos in their idea of interrelationality. Kwok Pui-Lan (1997) explicitly tackles the implications of ecology for Christology. She speaks of "an organic model of Christ". Christ calls himself the vine and his disciples the branches. This imaging of Christ allows us to move away from colonialism and anthropocentrism towards a more globally empowering sense of the Divine. This Christ is "epiphanic", he is not one but many and everyone has the potential to attain the status that Jesus attained. Christ-like actions are not restricted to interaction with others, but also extend to nature and the cosmos itself. The planet becomes one of the abused (I, pp 71-86). Feminist theologians have placed Christ at the centre of ecotheology both as redeemer and redeemed (I, p 84).

\section{CHRIST THE LIBERATOR WITH MANY FACES}

It is not surprising that many women place great emphasis on a Christ who liberates them. In the West, Rosemary Radford Ruether $(1983,1988)$ took the Jewish roots of Christianity seriously and so "was not prepared to merely brush over Hebraic messianic thought with the gloss of Greek metaphysics. Central to Jewish messianic hope was political action, since for the Jews religious and political life was synonymous" (I, p 34). Jesus acted as a sign of messianic blessedness, but rightly understood that he was one among many who signal that another order is possible, that which we call the Kingdom of God. Jesus did not fulfil all the expectations of the messiah. Ruether sees the events of Jesus' life as eschatological, as realities towards which we are still 


\section{A challenge to change developments in feminist theology}

moving, and not as historical events that form the base of an established church.

Mary Grey (1989b) agrees with Ruether that the Christ inspires to political action, but she wants to broaden the concept of liberation (I, pp 3739). Grey (1989b:87) writes: "Redemption seeks to transform the world at a deeper level than do movements for freedom and liberation - yet it must include them." "For Grey the redeeming power of Jesus lies in his ability to discover and make manifest the divine source of creative, relational energy in a way powerful enough to draw the whole world with him" (I, p 39). The deep and integral and all embracing process of liberation ties us into the cosmic/divine relationality which is "resurrection power in the world" (Grey 1989b:97).

Feminist thinkers took Liberation Theology further by mentioning explicitly the gender-aspect of poverty and oppression. Hungry children, homeless children, forced prostitution, an economy that makes particular groups of people - among them always many women - poorer and poorer, are situations that cry for liberation by the Divine and the true humanization of all men and women. Nellie Ritchie (1989:82), a feminist theologian from Argentina, states that a Christ meaningful to South America, having "nothing to do with an applied doctrine but with a truth to discover, with a response which translated into words and deeds, takes on historical truthfulness and liberating force" (I, pp 39-40). For example: the Mothers of the Plaza del Mayo embody liberation praxis in their struggle against powerlessness. They refuse the final triumph of death ( $\mathrm{l}, \mathrm{p} 40)$.

In Korea we meet an example of another striking feature of feminist Christology: traditional soteriological language is fused with soteriological language and practices offered by indigenous religion. As Chung Hyun Kyung (1990) once said: "I cannot believe that God was not present in Asia before the coming of the missionaries." She draws on the tales and ceremonies of Han-pu-ri. Han is a root-experience of the Korean people because it signifies their oppression and the "lump" in their spirit that has ensued. Women have experienced their own unique kind of "han", moving as they have from more or less equal status in ancient Korea to a place of silence and second-class citizenship in modern times. Traditional Christology has no salvific meaning for Korean women. Han-pu-ri does, however. It is a ritual, usually carried out by women-shamans and its purpose is to give voice to ghosts or people who have no other way of being heard. Chung Hyun Kyung argues that women's "han" has to be the starting point for theology in Korea. The most powerful image of Jesus for Korean women is as shaman. Shamanism always played a 
positive role in the lives of women as it presented an alternative to the patriarchal realities of Confucianism and other religions. (I, pp 89-90).

Black women theologians in the United States of America, who prefer to call themselves Womanists, are creating images of Christ against the background of a slave history in which Christ was used against them. Black women suffer multiple oppressions: being women, Black and often poor. Jacqelyn Grant (1989) wrote a book with the striking title, White women's Christ and black women's Jesus. The White Christ of traditional theology and slave masters and also the still predominantly White Christ of White women's feminist theology cannot give Black women a full sense of what liberation could be for them. Womanist Christology finds inspiration in Jesus, God incarnate, who signifies freedom (I, pp 44-49). This Jesus identifies with the suffering and struggles of Black women.

\section{CHRIST SOPHIA}

Several feminist theologians have taken up important issues of feminist Christologies and taken them together in the image of Christ Sophia, or, as Elisabeth Schüssler Fiorenza (1994) says: Jesus, Sophia's prophet. Sophia is Divine Wisdom. Her role and position are described in Proverbs 8. She is the first attribute of the Divine, Co-creatrix. She is the spokeswoman, the Voice of the Divine, voicing the Divine's passion for just relation. In the period between the Testaments Chokmah, Sophia, Wisdom personified was important. "Elizabeth Johnson is convinced that the early church used many of the traditions about the personified Sophia in order to come to an understanding of who Jesus was .... For Johnson the identification of Jesus with personified wisdom illustrates the importance of everyday living in the unfolding of the kingdom and it offers female metaphors as part of the divine process" (I, $p$ 108) (see Johnson 1993b:120-134).

Inclusion becomes the central element of salvation: those who are normally excluded are counted as friends, loved, not only tolerated or forgiven. The stories of the resurrection illustrate how Sophia rises again and again in unimaginable ways, asserting that the gift of life cannot be overcome even by extreme torture and death. Johnson, as is typical for feminist theologians, takes incarnation as a key concept in Christology. In the Christ/Sophia we see the Divine. In incarnation we witness the Divine in human flesh as an illustration of a core-characteristic of the Divine: $\mathrm{S} / \mathrm{He}$ lets herself be known and met in all creation. The passion for just relations and inspiring, caring and sustaining community can alter this world if Sophia/Christ is allowed to rise in everyone's life. Sophia is practical wisdom, embodied, in Her flesh can become Word. 


\section{THE FUTURE OF INDECENT/FEMINIST/WOMANIST THEOLOGY}

In their books Isherwood and McEwan give an account of the many thinkers of all parts of the world who took the courage and sharpened their wits to transgress the laws of decency - that is to think, write and behave according to the will of the fathers, as obedient, decent daughters, abnegating their own desires and ideas - and be what Marcella Althaus-Reid called, indecent theologians. They are creative. They are very critical, not as an intellectual game, but driven by anger and compassion for the many women who are not included, inspired, sustained or saved by the gospel in its dominant traditional words and images. The books of Isherwood and McEwan testify that indecent theologies are inspired by passion and compassion, and are worth being read by every theologian.

The future of indecent theologies is full of hope, and many theologians join their projects. What we see nowadays is that women - men who identify with women - touched by the Spirit of the Divine, by Her/His Sophia, gather in their own communities to inspire one another, criticize, empower one another, trying to find language and forms of relationships that are not contaminated by the great divides of patriarchy. Women synods gather to deepen theological understanding and to celebrate community with one another and the Divine. Whether the future of indecent theologies lies inside or outside the churches, is in the hands of the churches themselves.

\section{Works Consulted}

Althaus-Reid, M 1996. The indecency of her teaching: Notes for a cureb teaching of feminist theology in Europe, in Schüssler Fiorenza, E \& Copeland, S (eds), Feminist theology in different contexts, 133-140. London: SCM Press.

Althaus-Reid, M 2000. Indecent theology: Theological perversions in sex, gender and politics. London: Routledge.

Biezeveld, KE 2001. Challenging the tradition of the bodiless God: A way to inclusive monotheism?, in Van Henten, J W \& Houtepen, A (eds), Religious identity and the invention of tradition, 85-96. Assen: Royal Van Gorcum.

Bons-Storm, R 1991. Een mens met messiaanse kwaliteiten: Jezus Christus en het Vrouwenpastoraat, in Kalsky, M \& Witvliet, T (reds), De Gewonde Genezer: Christologie vanuit het perspectief van vrouwen uit verschillende culturen, 5169. Baarn: Ten Have.

Bons-Storm, R 1992. Pastoraat als bondgenootschap: Aanzet tot vernieuwing van de kerkelijke praktijk vanuit het vrouwenpastoraat. Kampen: Kok.

Brock, R 1988. Journeys by heart: A Christology of erotic power. New York: Crossroad.

Daly, M 1984. Pure lust: Elemental feminist philosophy. Boston, MA: Beacon Press. Grant, J 1989. White women's Christ, black women's Jesus. Atlanta, GA: Scholars Press. 
Grey, M 1989a. Weaving the connections: The promise of Process Thought for Christian theology. Katholieke Universiteit Nijmegen.

Grey, M 1989b. Redeeming the dream: Feminism, redemption and Christian tradition. London: SPCK.

Grey, M 1993. The wisdom of fools? Seeking revelation today. London: SPCK.

Heyward, C 1982. The redemption of God: A theology of mutual relation. Washington, DC: University of America Press.

Heyward, C 1989. The erotic as power and the love of God. New York: Collins. Hunt, M 1991. Fierce tenderness: A feminist theology of friendship. New York: Crossroad.

Hyun Kyung, C 1990. The struggle to be the sun again. London: SCM Press.

Isherwood, L 2001. Introducing feminist christologies. Sheffield: Sheffield Academic Press.

Isherwood, L \& McEwan, D [1993] 2001. Introducing feminist theology. Sheffield: Sheffield Academic Press.

Johnson, E A 1993a. Women, earth and Creator Spirit. Mahwah, NJ: Paulist Press.

Johnson, E 1993b. Redeeming the Name of Christ, in LaCugna, C M (ed), Freeing theology: The essentials of theology in feminist perspective, 120-134. New York: Harper \& Row.

Landman, C 2004. Review: Isherwood, L \& McEwan, D 2001. Introducing feminist theology. Sheffield: Sheffield Academic Press. HTS 60(3), 1233-1234.

McFague, S 1987. Models of God: Theology for a nuclear age. London: SCM Press.

McFague, S 1993. Super Natural Christians: How we should love. London: SCM Press.

Plaskow, J 1980. Sex, sin and grace: Women's experience and the theologies of Reinhold Niebuhr and Paul Tillich. New York: University Press of America.

Pui-Lan, K 1997. Ecology and Christology, in Feminist Theology 15. Sheffield: Sheffield Academic Press.

Radford Ruether, R 1983. Sexism and God-talk. London: SCM Press

Radford Ruether, R 1988. To change the world: Christology and cultural criticism. New York: Crossroad.

Ritchie, N 1989. Women and Christology, in Elsa, T (ed), Through her eyes: Women's theology from Latin America. Maryknoll, NY: Orbis Books.

Schüssler Fiorenza, E [1985] 1986. Bread not stone: The challenge of feminist biblical interpretation. Boston: Beacon Press, 1985. In the Dutch translation: Geen stenen voor brood. Hilversum: Gooi en Sticht, 1986.

Schüssler Fiorenza, E 1994. Jesus: Miriam's son, Sophia's prophet. New York: Continuum.

Whitehead, A N 1929. Process and reality. New York: Macmillan. 